\title{
Health Risks Associated with the Use of Water Mist Systems as a Cooling Intervention in Public Places in the Pilbara Region of Western Australia
}

\author{
Edmore Masaka 1, Sue Reed 1, Jacques Ooosthuizen 1, Margaret Davidson 1,2 \\ 1 Edith Cowan University; emasaka@our.ecu.edu.au \\ 2 Western Sydney University; ma.davidson@westernsydney@ edu.au \\ * Correspondence: emasaka@our.ecu.edu.au; Tel.:+61407993409
}

\begin{abstract}
The exposure of people to opportunistic premise plumbing pathogens (OPPPs) such as Legionella, Mycobacterium and Pseudomonas in aerosolised water has been linked to opportunistic infections. Water mist systems (WMS) that are used to cool public places by flash evaporation of tiny water aerosols are gaining prominence in hot climatic regions of Australia. Their potential to be colonised by OPPPs has not been adequately studied. The public health impact of OPPPs is significant, as Legionella caused $63 \%$ of waterborne disease case hospitalisations in the United States associated with drinking water systems during 2013-2014, and the incidence of Mycobacterium avium over the same period was 647 cases per 100,000. As WMS are part of premise plumbing, they have structural characteristics that can promote biofilm formation, as well as the presence of free-living amoebae (FLA), low residual disinfection levels, elevated water temperatures and oligotrophic conditions, all of which can promote OPPP inhabitancy. This review highlights the potential public health risks of using WMS as a cooling intervention in public places and advocates for their regulation in places of public assembly and entertainment.
\end{abstract}

Keywords: opportunistic premise plumbing pathogens; water mist system; Legionella; Mycobacterium; Pseudomonas; Acanthamoeba; Naegleria; health risks

1. Introduction to water mist systems (WMS) used as a cooling intervention in public places

In this review, water mist systems are defined as plumbing mechanisms installed in outdoor public places such as patios and gardens in order to reduce ambient temperatures and promote thermal comfort. The complete assembly of these systems includes a high-pressure water pump and lengths of high-pressure tubing, to which is connected slip lock nozzles at graduated distances. The nozzles are designed to atomise water into tiny aerosols that flash evaporate in the ambient atmosphere, thereby reducing surrounding temperatures by as much as $10^{\circ} \mathrm{C}$ and instantly making the thermal environment more comfortable for patrons. Figure 1 shows the typical layout of a water mist system. 


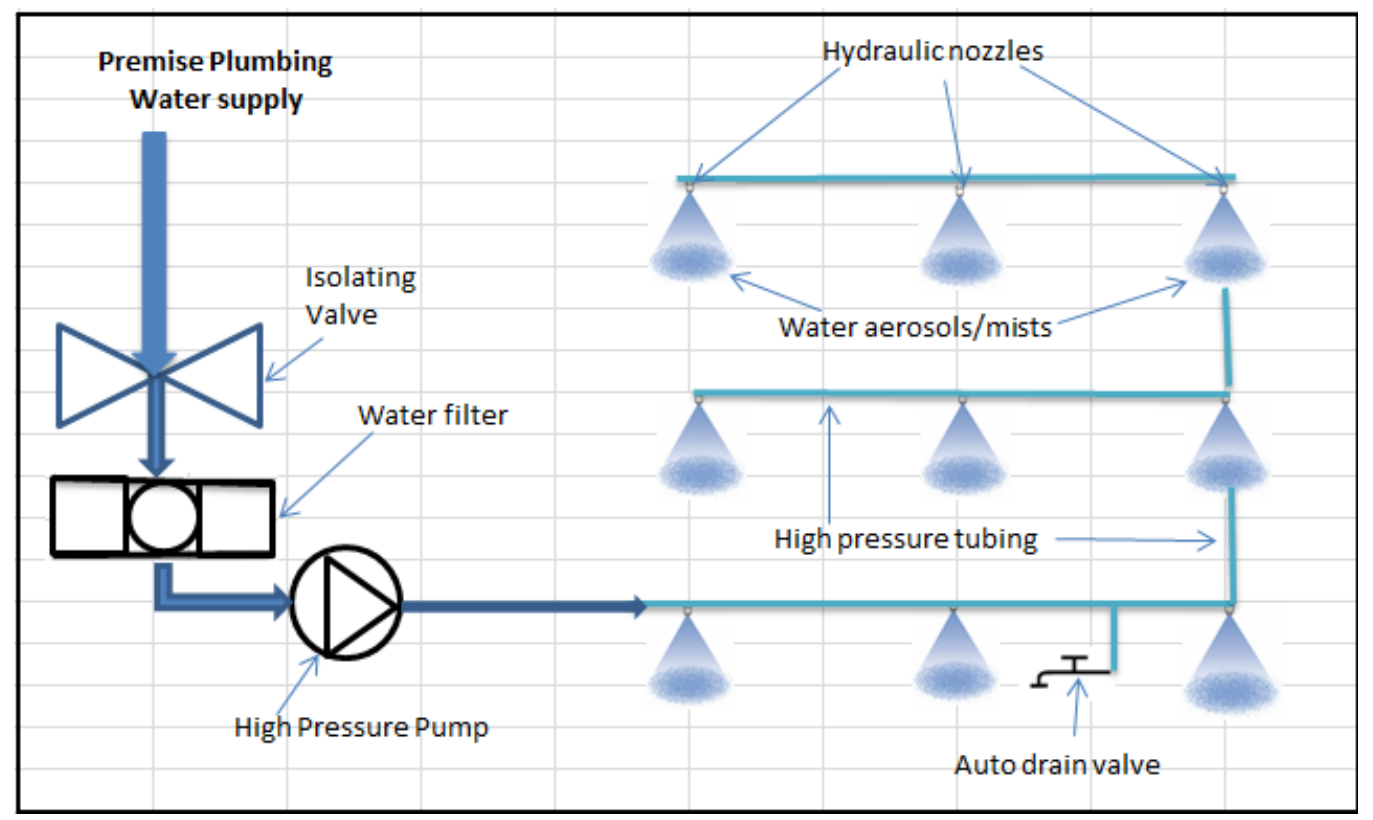

Figure 1. Schematic of a typical water mist system used for cooling public places.

Because of their minute particulate size $(0.3-10 \mu \mathrm{m})$, the aerosols released completely evaporate without wetting any surfaces. The lengths of high-pressure tubing and nozzles are fitted at regular distances under the roofs of covered areas, running around the perimeter of outdoor sitting areas to form a surrounding drape of cool air. A variation of these systems involves the fitting of the header tubing and nozzles to the front of mist fans that can dissipate the cooled air to distances of up to $10 \mathrm{~m}$, which has the advantage of driving away flies and other insects [1]. A study of WMS in Singapore [2] demonstrated that they could achieve thermal comfort at significantly lower energy costs in comparison to conventional air conditioning systems during periods of hot and humid climatic conditions. Dry-bulb temperature reductions of $12{ }^{\circ} \mathrm{C}$ have been recorded during studies of these systems $[3,4]$.

Water mist systems are part of premise plumbing, and the latter has been found to promote the colonisation and regrowth of opportunistic premise plumbing pathogens (OPPPs). A study to determine the most important factors affecting the presence and multiplication of opportunistic pathogens in premise plumbing [5] established that Legionella, Mycobacterium, Pseudomonas and Acanthamoeba have become ubiquitous in these environments, where they have been associated with opportunistic infections. Water mist systems are now popular as an effective and affordable means of achieving evaporative cooling in hot and humid climates. The Pilbara region of Western Australia sits north of the 26th parallel and experiences very hot summer temperatures that average $36-37^{\circ} \mathrm{C}$ from November to April and 28-29 ${ }^{\circ} \mathrm{C}$ from May to October [6]. In climate projections for the Pilbara region for 2070, this area is [6] foreseen to have an increasingly hotter and drier climate, with an expected annual average increase of $3{ }^{\circ} \mathrm{C}$ in summer and $4{ }^{\circ} \mathrm{C}$ in winter as compared to the 1990 baseline. Based on this increase in temperature extremes and the low energy costs associated with the use of WMS for cooling ambient temperatures, it is reasonably expected that the uptake and use of WMS for evaporative cooling in this climatic region may also increase. The increasing global temperatures attributed to climate change have the potential to increase the demand for these systems [7].

The majority of research on the application of WMS for cooling interventions has been experimental and has primarily focused on establishing their operational efficiencies, economies and optimum design parameters [2, 8-11]. In contrast, there has been limited investigation of the public health risks presented by OPPP colonisation of these systems. Whilst acknowledging that WMS using misting fans are effective at reducing ambient temperatures, a study examining the performance of water 
misting fans [2] determined that the resultant increase in relative humidity promoted the growth of bacteria and fungi. Extensive research of other premise plumbing installations, such as drinking water systems [12,13], cooling towers [14-16] (13-15), showers, water taps and faucets [17-20], have established that opportunistic premise plumbing pathogens such as Legionella pneumophila, Mycobacterium avium, Pseudomonas aeruginosa, Acanthamoeba and Naegleria fowleri have become ubiquitous in such systems. American research into the public health risks associated with OPPPs has focused on hospitals and aged care facilities [18, 20-23], whilst some Asian studies have centred on operational efficiency $[2,3]$. There is a substantial gap in knowledge regarding the public health risks associated with WMS used for cooling public places, particularly their potential to be colonised by OPPPs and the promotion of their regrowth. In identifying research needs for OPPPs, [24] it has been highlighted that there is a need to investigate environments promoting their growth and multiplication. This review examines and describes WMS used for cooling public places, focusing on their ability to promote the growth and multiplication of OPPPs. We highlight the five major OPPPs implicated in waterborne diseases, namely, L. pneumophila, M. avium, P. aeruginosa, Acanthamoeba and N. fowleri.

\section{Opportunistic Premise Plumbing Pathogens and their public health impact}

OPPPs are microorganisms which have become ubiquitous in water distribution systems (WDS), including that part of plumbing beyond the supply of water service mains $[5,25,26]$. Because of their tendency to cause illness in people with predisposing risk factors, such as compromised immunity, the elderly and the young, these pathogens have been called "opportunistic" [24, 26]. Some of the major OPPPs which have been associated with WDS and premise plumbing are L. pneumophila, $M$. avium, P. aeruginosa, Acanthamoeba and N. fowleri [13, 26-30].

\subsection{L. pneumophila}

L. pneumophila is one of the most recognised OPPPs associated with premise plumbing and several outbreaks of waterborne pneumonic disease called Legionellosis [31-36]. L. pneumophila has been isolated from cooling towers, warm water baths, water fountains [16, 37, 38], showers [39, 40] and drinking water systems [41-43]. This OPPP has also been found to grow in amoebae [44, 45], and this phenomenon has been found to make it resistant to disinfection [46-48].

\subsection{M. avium}

M. avium belongs to a group of environmental nontuberculous mycobacteria (NTM). These opportunistic pathogens are capable of causing pulmonary diseases in people with compromised immunity, such as those suffering from AIDS [49-51]. The colonisation of this pathogen in premise plumbing has been demonstrated in several studies of potable water systems [52-54], with the bacteria isolated from drinking water systems [55-57], hospital plumbing systems [29, 58, 59] and household plumbing [60]. In a study [61] of 21 isolates of natural waters, it was determined that aerosolisation is a potential route of infection for this pathogen. Another study of transmission pathways for opportunistic pathogens confirmed that aerosolisation of M. avium was possible [62]. M. avium is able to resist disinfection in premise plumbing by its ability to survive inside amoebae $[63,64]$.

\subsection{P. aeruginosa}

P. aeruginosa is a hardy and versatile opportunistic pathogen with the ability to adapt and survive a broad range of environmental conditions [65]. This bacterium has a tendency to favour oligotrophic conditions, which enables it to flourish in premise plumbing waters [66]. Transmission 
of $P$. aeruginosa can occur through exposure to contaminated water and is known to cause an aggressive pneumonia in people suffering from cystic fibrosis and nosocomial infections in hospital patients [25]. This bacterium has become one of the most commonly isolated infectious bacteria in hospital intensive care units [67], as well as in hospital tap waters [23, 68], shower heads and hydrotherapy pools [69-71]. Chlorine disinfection resistance contributes to this opportunistic pathogen's survival in premise plumbing [43, 72, 73]. An Australian study to determine the growth of opportunistic pathogens in seven drinking water and six recycled schemes isolated high numbers of $P$. aeruginosa in one of the drinking water systems [26].

\subsection{Acanthamoeba}

Acanthamoeba is a protozoan with the ability to live in varied environments, such as environmental and drinking water systems [74, 75], tap water [76], well water [76], hospital waters $[77,78]$ aquatic facilities [79, 80] and recycled water [26]. Acanthamoeba has gained attention as the infectious agent for a central nervous system disease called granulomatous amoebic encephalitis (GAE), which affects people with weakened immunity, as well as Acanthamoeba keratitis, an infection of the corneal epithelium [24, 26, 80]. A significant characteristic of Acanthamoeba in premise plumbing is its ability to act as a host of OPPPs such as L. pneumophila, P. aeruginosa and M. avium [25, $45,46,81-83$ ]. A study of amoeba-related health risks in potable water systems [44] advocated for its monitoring to complement existing water quality monitoring approaches. By acting as a host of other OPPPS in premise plumbing, Acanthamoeba can shield them from chlorine disinfection [46, 47, 64, 83-86].

\subsection{N. fowleri}

$N$. fowleri, the only pathogenic species of its genus, has become a major concern because it is the agent of fatal primary amoebic meningoencephalitis (PAM), which is contracted by aspiration of contaminated water aerosols up the nasal passage [87-89]. This free-living amoebae (FLA) has been detected in drinking water systems [26, 88, 90], with domestic water supply systems being implicated in a South Australian outbreak of the disease in children exposed to bathing water [91]. $N$. fowleri has also been detected in recreational waters [92], premise plumbing [93], irrigation systems [94] and rain water tanks in Queensland [95]. This pathogen is resistant to standard chlorine disinfection concentrations [96-98]. Super chlorination is the recommended method for ridding contaminated water systems of this pathogen [99].

\subsection{Public health impact of Opportunistic premise plumbing pathogens}

The public health impact of OPPPs is significant. It has been estimated that Legionella is responsible for almost $2 \%-15 \%$ of patients hospitalised globally with community acquired pneumonia [100]. The American Center for Disease Control (CDC) reported 432 cases of waterborne diseases between 2011 and 2012 [51, 101]. One hundred and two out of the 432 cases were hospitalised, with $66 \%$ of the hospital admissions being caused by L. pneumophila. The incidence rate for M. avium was 647 cases per 100,000 persons, with a higher prevalence in the immune-compromised population [51, 101]. The cost of managing outbreaks of waterborne diseases caused by OPPPs can be significant. A study of healthcare costs related to diseases partly transmitted by water estimated the hospitalisation costs for patients affected by Legionnaires' disease and NTM in the United States to be $\$ 33,336$ and $\$ 25,985$, respectively, making this the highest episode cost associated with the outbreak of waterborne diseases. The World Health Organization (WHO) has reported that cases of Legionella infections in Europe alone increased from 1161 per year in 1994 to 4546 in 2004, and in all these cases, the mode of transmission was via the inhalation of contaminated water aerosols [102]. 
Cases of Legionellosis in Australia are increasing, as shown in Figure 2, with an average of 374 cases being reported annually to the Notifiable Disease Surveillance System (NDSS) in the 10-year period from 2008 to 2018 [103]. The combined reporting of L. pneumophila and Legionella longbeachae cases in Australia also tends to obscure any trends associated with exposure routes, considering that one is soilborne (L. longbeache) and the other is waterborne (L. pneumophila). In Western Australia, the Legionellosis rate varied between 1.5 and 4.5 cases per 100,00 population (2014-2018), with the greatest number of cases in persons aged over 55 years [104].

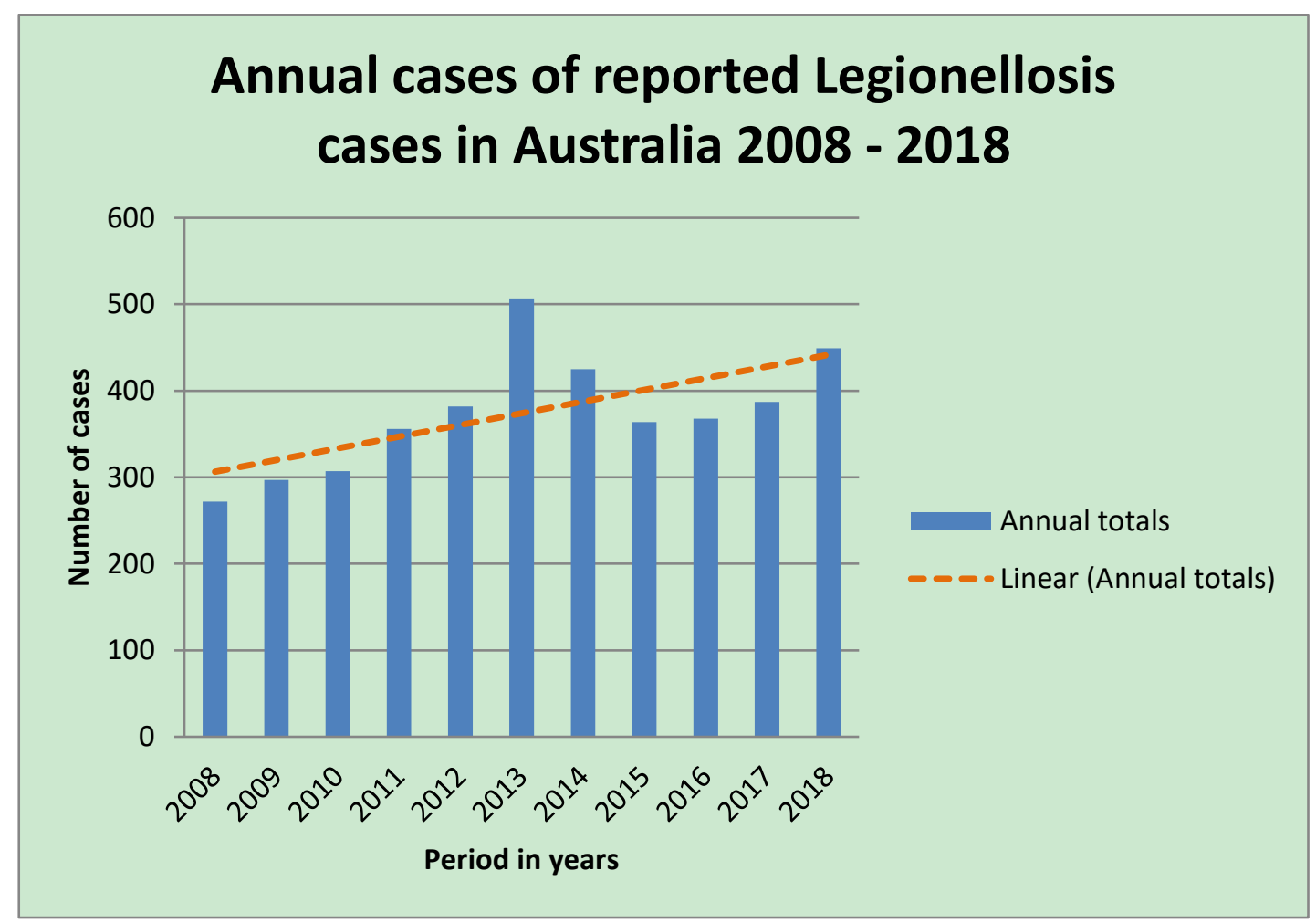

Figure 2. Annual reported cases of Legionellosis in Australia (2008-2018), adapted from the Department of Health, National Notifiable Disease Surveillance System [103].

FLA are now regarded as emerging pathogens of public health importance (PAM) [105]. A total of 19 water-related PAM cases were recorded in Australia between 1960 and 1980 [95], with 111 cases of the same infection being recorded in the United States between 1962 and 2008 [106]. In spite of its common occurrence throughout the world and its high case fatality rate, PAM disease is not listed as a notifiable waterborne disease in several countries [107, 108]. A survey of microbial keratosis was undertaken in Queensland between 2005 and 2015, and researchers estimated the case rate to be 0.66 cases per 10,000 people, with the most common causative agent being $P$. aeruginosa $(17.7 \%)$, while Acanthamoeba accounted for $1 \%$ of cases [109]. Opportunistic infections caused by M. avium and $P$. aeruginosa may be underestimated because they are not notifiable in most countries [51]. In Australia, NTM infection, inclusive of M. avium, is a notifiable disease in Queensland [110]. In 2015, the notification rate for NTM was 25.9 cases per 100,000 population [110]. There have been fewer than $300 \mathrm{~N}$. fowleri infections worldwide since it was first identified in 1965, and the most recent case in Australia was reported in 2019 [111].

\section{Water mist systems, bioaerosol formation and inhalation risk}

The ability to atomise pressurised water and release it into the ambient air as aerosols has already been discussed as the key feature by which WMS cool ambient temperatures in public places to achieve thermal comfort. The aerosols normally fall in the $0.3-10 \mu \mathrm{m}$ size range, and those measuring $5 \mu \mathrm{m}$ or less can be deposited into the lungs by inhalation and cause infections [112]. 
Inhalation of bioaerosols as the route of infection for OPPPs has been investigated in a number of studies. Outbreaks of Legionellosis have been linked to the exposure and inhalation of $L$. pneumophila released from cooling towers [113-115], air scrubbers [116], decorative water fountains [117] and air conditioning [36].

Inhalation of aerosols contaminated with Mycobacterium can cause granulomatous respiratory diseases [24]. A study investigating NTM growth and aerosol formation from 18 warm water pools established that $76 \%(n=18)$ of air and water samples tested positive for this OPPP [118]. Mycobacterium has also been isolated from drinking water distribution systems [52, 54] and household plumbing $[60,119]$. P. aeruginosa, the other OPPP found to colonise and grow in water distribution systems and premise plumbing [13, 18, 30, 120], shares similar characteristics to $L$. pneumophila and M. avium that make it transmissible by inhalation of aerosols [68, 121]. Inhalation of water aerosols containing amoeba species can cause a number of infections, such as PAM caused by N. fowleri [122] and GAE caused by Acanthamoeba [80].

Although there are a significant number of studies on the inhalation risk of OPPPs residing in engineered water systems such as cooling towers, scrubbers, drinking water distribution systems, hospital plumbing and so forth, an understanding of the magnitude of this risk in WMS used as a cooling intervention in public places is still lacking. The sampling and analysis of bioaerosols generated by WMS may help in understanding and describing this inhalation risk and the potential for skin and eye infections associated with aerosolisation, since infectious organisms could be directed into eyes, ears and damaged skin (burns, blisters and rashes).

\section{Water Misting Systems and factors promoting colonisation and growth of OPPPs}

\subsection{Biofilm formation}

The formation of biofilms in premise plumbing systems has been identified as a significant factor in OPPP colonisation potential [24, 25, 123]. Being engineered water distribution systems, WMS used for cooling intervention in public places form part of premise plumbing; hence, they present similar risk factors of biofilm formation and colonisation by OPPPs. Biofilms are complex heterogeneous colonies consisting of bacteria, fungi, protists and other microbial organisms that grow as native communities in water distribution or storage systems [124], as well as other terrestrial environments such as medical devices [125] and food preparation surfaces [126, 127]. They have been referred to as aftergrowth, consisting of a fine layer of microorganisms living in aquatic conditions joined in an extracellular matrix of various shapes and sizes of filaments and deposits [24, 128-130]. The probability of biofilms forming on the internal surfaces of WMS is high considering the presence of copious amounts of nonsterile water which is in constant contact with internal surfaces as it circulates in the system during operation [131].

This process of biofilm formation, also known as biofouling [131], is possible due to various extreme environmental conditions of temperature, $\mathrm{pH}$ and pressure that may exist in these water distribution systems [132]. The biofilms form an ecological niche for the OPPPs because of their ability to provide conducive and nutritive conditions for microbial growth, as well as protection from disinfection chemicals and other bactericidal agents [5]. The OPPPs residing in biofilms of water systems are capable of being released into the water phase and thus become significant sources of waterborne pathogens [133]. A study of biofilms in a drinking water system [134] determined that almost $95 \%$ of the microbiological population in drinking water systems reside in biofilms as compared to approximately $5 \%$ in the water phase. This means that the standard approach of collecting water samples from the water phase only is unable to assist in understanding the extent of biofilm growth in water distribution systems [134]. The sampling and analysis of biofilm samples from WMS used as a cooling intervention is recommended to provide an insight into their potential as sources of OPPPs.

\subsection{Temperature}


Elevated water temperatures in distribution systems have been found to promote the growth of OPPPs $[25,129,135,136]$. According to Falkinham et al., survival at elevated water temperatures is one of the critical adaptation features which enables L. pneumophila, M. avium and P. aeruginosa to thrive in water systems [51]. The WMS used for cooling public places in the Pilbara region of Western Australia are exposed to extremes of summer temperatures averaging $36-37^{\circ} \mathrm{C}$ from November to April and $28-29^{\circ} \mathrm{C}$ from May to October [137]. These hot climatic conditions often result in equally elevated water temperatures in Pilbara water distribution systems, as shown in Figure 3 [138], which could speed up the colonisation and spread of OPPPs in these systems.

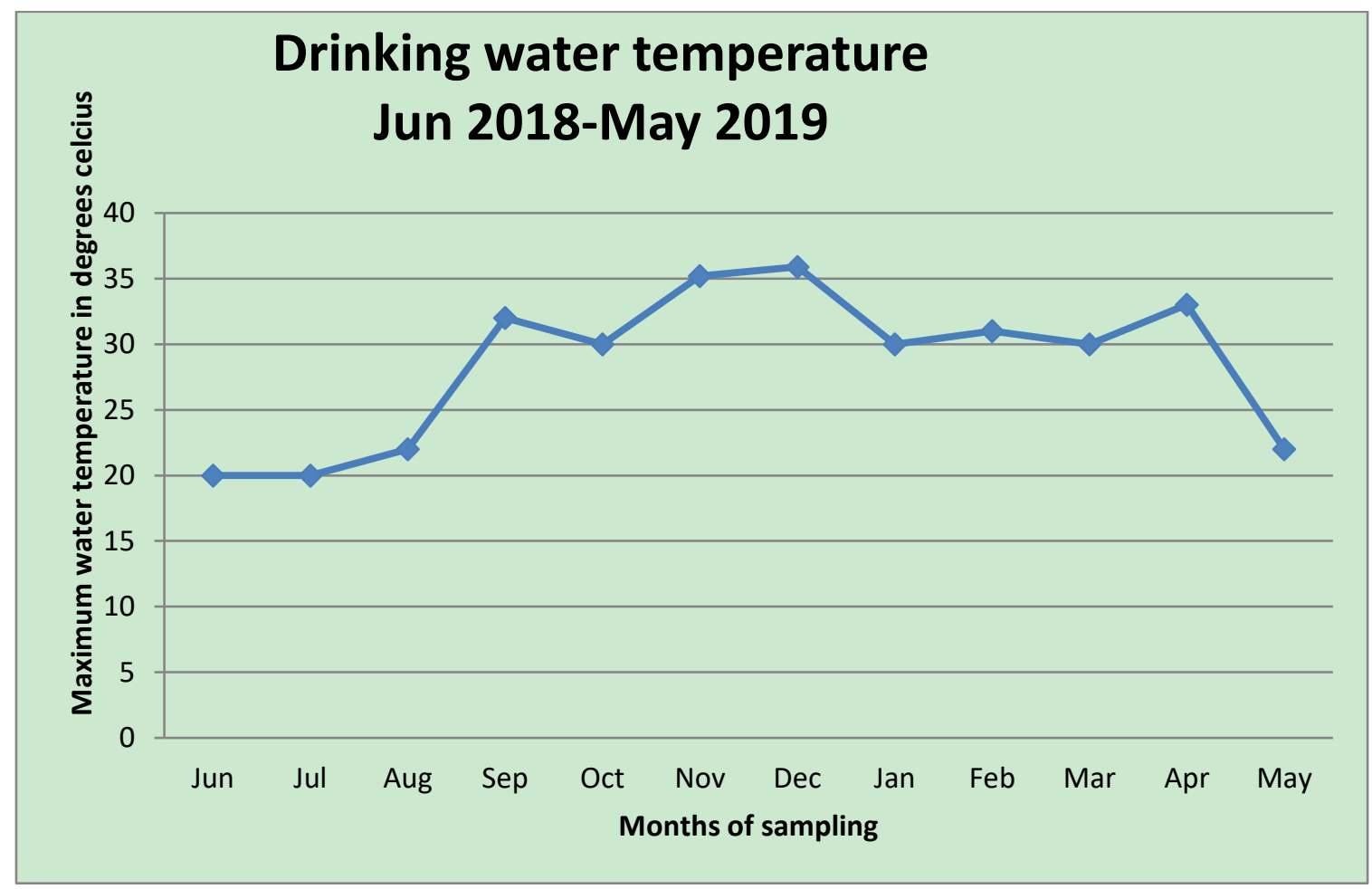

Figure 3. Water temperatures in a Pilbara water distribution system in the study area, June 2018 to May 2019 [138].

A study of potable and reuse water schemes operating in the various climatic regions of Australia [26] established the important part played by higher water temperatures in the increased occurrence of N. fowleri and L. pneumophila in those systems situated in warmer climates. Based on these observations, it can be reasonably expected that the water temperature profile of WMS used for cooling public places in this warm climatic region will mirror that shown in Figure 3 [138]. Determining the water temperature profile of WMS is important to understand its possible influence on the potential of OPPP colonisation and regrowth. In addition to the effect of warm temperatures discussed above, the presence of FLA in water distribution systems can aid the regrowth of OPPPs $[43,129,139,140]$.

\subsection{Presence of FLA}

The part played by FLA in amplifying the number and virulence of OPPPs in engineered water systems is now widely acknowledged [13, 83], with Legionella and Mycobacterium showing a greater ability to proliferate in this manner [76]. The monitoring of amoebae in drinking water systems as part of a water quality monitoring program has also been advanced as an effective measure [44, 105].

Through a process of phagocytosis, FLA such as Acanthamoeba in water distribution systems [13] feed on other OPPPs including Legionella, Mycobacterium and Pseudomonas [141, 142]. When subjected to unfavourable growth conditions, the FLA develop into cysts with thick walls which shield the 
OPPPs growing in them from destruction by disinfectants such as chlorine [76, 83, 141, 142]. Furthermore, the ability of this beneficial relationship to increase the virulence of the OPPPs growing inside the FLA has been well documented, particularly for Legionella $[25,26,51,143]$ and Mycobacterium [82, 144]. In contrast, phagocytosis of Pseudomonas is restricted by its ability to produce a secretion which destroys the amoeba [145].

In view of the important part played by FLA, particularly Acanthamoeba, in the regrowth and amplification of OPPPs, as well as their virulence in water distribution systems, it is important that WMS used for cooling public places in the Pilbara region of Western Australia are investigated for this protozoan [44]. The water quality monitoring data, shown in Table 1, obtained from a Pilbara water distribution system indicated that approximately $10.6 \%(n=33)$ and $3.2 \%(n=7)$ of water samples collected between 2016 and 2018 tested positive for thermophilic amoebae and thermophilic Naegleria, respectively, which encompass Acanthamoeba and N. fowleri [146, 147].

Table 1. Occurrence of thermophilic amoebae and thermophilic Naegleria in a Pilbara drinking water system in the study area, 2016-2018 $(\mathrm{n}=216)[146,147]$.

\begin{tabular}{|l|c|c|c|c|}
\hline Year & $\mathbf{2 0 1 6}$ & $\mathbf{2 0 1 7}$ & $\mathbf{2 0 1 8}$ & Total \\
\hline Thermophilic amoebae +ve & 13 & 13 & 7 & 33 \\
\hline Thermophilic Naegleria +ve & 4 & 2 & 1 & 7 \\
\hline No. of samples -ve for both microorganisms & 55 & 57 & 64 & 176 \\
\hline Totals & $\mathbf{7 2}$ & $\mathbf{7 2}$ & $\mathbf{7 2}$ & $\mathbf{2 1 6}$ \\
\hline
\end{tabular}

\subsection{OPPPS and resistance to chlorine disinfection}

Chlorine has been successfully used to disinfect water over the last 100 years [148]. It has been described as one of the most important public health interventions of the century [149]. At the right $\mathrm{pH}(6.5-8.5)$ [150], temperature $\left(20-29^{\circ} \mathrm{C}\right)$ [151] and turbidity (1 nephelometric turbidity unit (NTU)) [150], chlorine is able to provide an adequate residual disinfectant effect. However, several studies have demonstrated that under certain environmental conditions, OPPPs can become resistant to conventional water disinfection, particularly chlorine and its derivatives [43, 46, 64, 81, 83, 152]. $M$. avium has demonstrated resistance to chlorine disinfection when engulfed by Acanthamoeba [26, 63]. Biofilms also shield this pathogen from chlorine disinfection [25, 64]. The presence of slime or biofilm adds to the survival of $P$. aeruginosa in the presence of chlorine disinfectant $[72,153,154]$.

Most of the studies of OPPP resistance to chlorine disinfection have focused on drinking water systems, recycled water schemes and cooling towers. The impact of this phenomenon on WMS used as a cooling intervention in public places has not been adequately studied. Most WMS are connected to scheme water supplied by licensed and regulated operators [155]. However, due to geographical location and remoteness, a few of these systems are connected to onsite borehole water supplies that are locally managed. Chlorination is the most common means of disinfection for Australian water supplies, with a minimum target of $0.5 \mathrm{mg} / \mathrm{L}$ residual chlorine recommended [150]. The larger scheme water operators use chlorine dioxide for disinfection, while the smaller ones prefer liquid sodium hypochlorite or calcium hypochlorite.

The presence of FLA is an environmental variable that can promote bacterial pathogen resistance to chlorine disinfection [43, 46, 83, 141]. Bacteria engulfed by Acanthamoeba castellanii can survive exposure to residual chlorine concentrations of $10 \mathrm{mg} / \mathrm{L}$ over $24 \mathrm{~h}$ and form cysts when exposed to concentrations greater than $4 \mathrm{mg} / \mathrm{L}$ [81].

Since chlorination is the main form of disinfection for water supplies connected to WMS, an investigation of the effectiveness of this disinfection method in preventing or limiting the colonisation and regrowth of OPPPs in these systems is warranted. 


\subsection{OPPPs and low total organic carbon (TOC) concentration (Oligotrophic conditions)}

The ability of OPPPs to thrive in premise plumbing systems with low carbon concentrations is another important characteristic of their persistence [13, 124, 156]. Low-carbon or oligotrophic environments are characteristic of most premise plumbing and drinking water systems [5]. The nitrifying bacterial autotrophs present in low-carbon waters fix available carbon, subsequently making it available to heterotrophic organisms such as OPPPs, which are then able to metabolise the carbon $[5,157]$. Through this process, low-carbon water environments existing in premise plumbing systems are able to select for OPPPs over other microorganisms. A positive relationship with organic carbon has been established between L. pneumophila [158], P. aeruginosa [66] and M. avium [159].

To better understand the impact of oligotrophic conditions on the ability of OPPPs to colonise and regrow in these WMS, the sampling and analysis of water from these systems for TOC concentration is needed to determine potential sustainability.

\section{Conclusion}

The emerging use of WMS as a cooling intervention in public places is increasing due to their ability to quickly achieve thermal comfort at lower operational costs. These systems share similar characteristics of biofilm formation, elevated temperatures, growth of FLA and low organic carbon concentration with premise plumbing, from which colonisation and regrowth of OPPPs such as $L$. pneumophila, M. avium, P. aeruginosa, Acanthamoeba and N. fowleri has been established. The WMS aerosolise water into tiny inhalable particles which can then transmit pathogens to hosts through inhalation, as well as through contamination of surfaces and the skin/eyes. An investigation of the health risks associated with the use of WMS as a cooling intervention is warranted to better understand their public health impact and inform strategies to manage the risks they may pose.

\section{Conflict of interest}

The authors declare no conflict of interest.

\section{Funding}

This study is partly funded by Edith Cowan University and the Local Health Authorities Analytical Committee of Western Australia. 


\section{References}

1. Ozmist. Alfresco cooling Victoria, Australia: Ozmist; n.d. [cited 2019 June 26, 2019]. Product brochure]. Available

from: https://www.ozmist.com.au/static/uploads/files/alfresco-cooling-ozmist-brochure-18-2019-wfxfkhztrkbo. pdf.

2. Wong NH, Chong AZM. Performance evaluation of misting fans in hot and humid climate. Building and Environment. 2010;45(12):2666-78.

3. Farnham C, Emura K, Mizuno T. Evaluation of cooling effects: outdoor water mist fan. Building Research \& Information. 2015;43(3):334-45.

4. Duan Z, Zhan C, Zhang X, Mustafa M, Zhao X, Alimohammadisagvand B, et al. Indirect evaporative cooling: Past, present and future potentials. Renewable and Sustainable Energy Reviews. 2012;16(9):6823-50.

5. Wang H, Edwards MA, Falkinham JO, Pruden A. Probiotic Approach to Pathogen Control in Premise Plumbing Systems? A Review. Environmental Science \& Technology. 2013;47(18):10117.

6. Loechel Barton, Hodgkinson Jane H , Kieren. M. CSIRO Regional Climate Vulnerability Assessment: The Pilbara. Western Australia: CSIRO; 2011 July 21, 2011.

7. Hansen J, Sato M, Ruedy R, Lo K, Lea DW, Medina-Elizade M. Global temperature change. Proceedings of the National Academy of Sciences. 2006;103(39):14288-93.

8. Chen Q, Pan N, Guo Z-Y. A new approach to analysis and optimization of evaporative cooling system II: Applications. Energy. 2011;36(5):2890-8.

9. Chen Q, Yang K, Wang M, Pan N, Guo Z-Y. A new approach to analysis and optimization of evaporative cooling system I: Theory. Energy. 2010;35(6):2448-54.

10. Lyons O, Persoons T, Murray D. Particle sizing and flow measurements in an atomizing mist jet nozzle: A shadowgraphy approach. Transfer. 2010;116(1):167-72.

11. Xuan YM, Xiao F, Niu XF, Huang X, Wang SW. Research and application of evaporative cooling in China: A review (I) - Research. Renewable \& Sustainable Energy Reviews. 2012;16(5):3535-46.

12. Whiley H, Keegan A, Fallowfield H, Bentham R. Detection of Legionella, L. pneumophila and Mycobacterium Avium Complex (MAC) along Potable Water Distribution Pipelines. International Journal of Environmental Research and Public Health. 2014;11(7):7393-.

13. Falkinham JO, Pruden A, Edwards M. Opportunistic Premise Plumbing Pathogens: Increasingly Important Pathogens in Drinking Water. Pathogens (Basel, Switzerland). 2015;4(2):373-86.

14. Luksamijarulkul P, Kornkrerkkiat S, Saranpuetti C, Sujirarat D. Predictive factors of Legionella pneumophila contamination in cooling tower water. Air, Soil and Water Research. 2014:11.

15. Lau R, Maqsood S, Harte D, Caughley B, Deacon R. Prevalence of Legionella strains in cooling towers and legionellosis cases in New Zealand. Journal of environmental health. 2013;75(6):82.

16. Kim C, Jeon S, Jung J, Oh Y, Kim Y, Lee J, et al. Isolation of Legionella pneumophila from cooling towers, public baths, hospitals, and fountains in Seoul, Korea, from 2010 to 2012. Journal of environmental health. 2015;77(6):58.

17. Cassier P, Landelle C, Reyrolle M, Nicolle MC, Slimani S, Etienne J, et al. Hospital washbasin water: risk of Legionella-contaminated aerosol inhalation. The Journal of hospital infection. 2013;85(4):308.

18. Williams MM, Armbruster CR, Arduino MJ. Plumbing of hospital premises is a reservoir for opportunistically pathogenic microorganisms: A review. Biofouling. 2013;29(2):147-62. 
19. Shareef A, Mimi Z. The Hospital Tap Water System as a Source of Nosocomial Infections for Staff Members and Patients in West Bank Hospitals. Environmental Forensics. 2008;9(2):226-30.

20. Bilinski P, Holownia P, Parafinska K, Tomaszewski W, Kapka-Skrzypczak L. Managing water safety in healthcare. Part 1 - Strategies and approaches for waterborne pathogen control. Annals of Agricultural and Environmental Medicine. 2012;19(3):395-402.

21. Kozicki ZA, Cwiek MA, John EL, Jr., Rodabaugh G, Jr NT, Stephanie JSB-K. Waterborne pathogens: A public health risk in US hospitals. American Water Works Association Journal. 2012;104(1):52.

22. Trautmann M, Lepper PM, Haller M. Ecology of Pseudomonas aeruginosa in the intensive care unit and the evolving role of water outlets as a reservoir of the organism. American journal of infection control. 2005;33(5 Suppl 1):S41-9.

23. Shareef A, Mimi Z. The hospital tap water system as a source of nosocomial infections for staff members and patients in West Bank hospitals. Environmental Forensics. 2008;9(2-3):226-30.

24. Pruden A, Edwards M, Falkinham III J. State of the science and research needs for opportunistic pathogens in premise plumbing. Water Research Foundation. 2013:183.

25. Falkinham JO. Common Features of Opportunistic Premise Plumbing Pathogens. International Journal of Environmental Research and Public Health. 2015;12(5):4533-.

26. Storey MV, Kaucner CE. Understanding the growth of opportunistic pathogens within distribution systems: WQRA; 2009.

27. Feazel LM, Baumgartner LK, Peterson KL, Frank DN, Harris JK, Pace NR. Opportunistic pathogens enriched in showerhead biofilms. Proceedings of the National Academy of Sciences. 2009;106(38):16393-9.

28. Berk SG, Gunderson JH, Newsome AL, Farone AL, Hayes BJ, Redding KS, et al. Occurrence of infected amoebae in cooling towers compared with natural aquatic environments: Implications for emerging pathogens. Environmental Science and Technology. 2006;40(23):7440-4.

29. Shin JH, Lee EJ, Lee HR, Ryu SM, Kim HR, Chang CL, et al. Prevalence of non-tuberculous mycobacteria in a hospital environment. Journal of Hospital Infection. 2007;65(2):143-8.

30. Bédard E, Prévost M, Déziel E. Pseudomonas aeruginosa in premise plumbing of large buildings. MicrobiologyOpen. 2016;5(6):937-56.

31. Schlech WF, III, Gorman GW, Payne MC, Broome CV. Legionnaires' Disease in the Caribbean: An Outbreak Associated With a Resort Hotel. Archives of Internal Medicine. 1985;145(11):2076-9.

32. De Boer J, Peeters M, van Ketel R, Speelman P, Kool J, Conyn-van Spaendonck M, et al. A large outbreak of Legionnaires' disease at a flower show, the Netherlands, 1999. Emerg Infect Dis. 2002;8(1):37-43.

33. Silk BJ, Moore MR, Bergtholdt M, Gorwitz RJ, Kozak NA, Tha MM, et al. Eight years of Legionnaires' disease transmission in travellers to a condominium complex in Las Vegas, Nevada. Epidemiology and Infection. 2012;140(11):1-10.

34. Cohn PD, Gleason JA, Rudowski E, Tsai SM, Genese CA, Fagliano JA. Community outbreak of legionellosis and an environmental investigation into a community water system. Epidemiology and infection. 2015;143(6):1322.

35. Craun GF, Brunkard JM, Yoder JS, Roberts VA, Carpenter J, Wade T, et al. Causes of outbreaks associated with drinking water in the United States from 1971 to 2006. Clinical Microbiology Reviews. 2010;23(3):507-28.

36. Bennett E, Ashton M, Calvert N, Chaloner J, Cheesbrough J, Egan J, et al. Barrow-in-Furness: a large community legionellosis outbreak in the UK. Epidemiology and infection. 2014;142(8):1763-77. 
37. Borella P, Montagna MT, Stampi S, Stancanelli G, Romano-Spica V, Triassi M, et al. Legionella contamination in hot water of Italian hotels. Applied and Environmental Microbiology. 2005;71(10):5805-13.

38. Buse HY, Schoen ME, Ashbolt NJ. Legionellae in engineered systems and use of quantitative microbial risk assessment to predict exposure. Water Research. 2012;46(4):921-33.

39. Bauer M, Mathieu L, Deloge- Abarkan M, Remen T, Tossa P, Hartemann P, et al. Legionella bacteria in shower aerosols increase the risk of pontiac fever among older people in retirement homes. Journal of Epidemiology and Community Health. 2008;62(10):913-20.

40. Dennis PJL, Wright AE, Rutter DA, Death JE, Jones BPC. Legionella pneumophila in aerosols from shower baths. Journal of Hygiene. 1984;93(2):349-53.

41. Stout JE, Yu VL, Yee YC, Vaccarello S, Diven W, Lee TC. Legionella pneumophila in residential water supplies: Environmental surveillance with clinical assessment for Legionnaires' disease. Epidemiology and Infection. 1992;109(1):49-57.

42. Whiley H. Legionella risk management and control in potable water systems: Argument for the abolishment of routine testing. International Journal of Environmental Research and Public Health. $2017 ; 14(1)$.

43. Wang H, Edwards M, Falkinham JO, Pruden A. Molecular survey of the occurrence of Legionella spp., Mycobacterium spp., Pseudomonas aeruginosa, and amoeba hosts in two chloraminated drinking water distribution systems. Applied and environmental microbiology. 2012;78(17):6285-94.

44. Codony F, Pérez LM, Adrados B, Agustí G, Fittipaldi M, Morató J. Amoeba-related health risk in drinking water systems: could monitoring of amoebae be a complementary approach to current quality control strategies? Future microbiology. 2012;7(1):25-31.

45. Żbikowska E, Kletkiewicz H, Walczak M, Burkowska A. Coexistence of Legionella pneumophila Bacteria and Free-Living Amoebae in Lakes Serving as a Cooling System of a Power Plant. Water, Air, \& Soil Pollution. 2014;225(8):1-10.

46. Thomas V, Bouchez T, Nicolas V, Robert S, Loret J, Levi Y. Amoebae in domestic water systems: resistance to disinfection treatments and implication in Legionella persistence. Journal of applied microbiology. 2004;97(5):950-63.

47. Dupuy M, Mazoua S, Berne F, Bodet C, Garrec N, Herbelin P, et al. Efficiency of water disinfectants against Legionella pneumophila and Acanthamoeba. Water research. 2011;45(3):1087-94.

48. Cooper IR, Hanlon GW. Resistance of Legionella pneumophila serotype 1 biofilms to chlorine-based disinfection. Journal of Hospital Infection. 2010;74(2):152-9.

49. Drake TA, Herron Jr RM, Hindler JA, Berlin OGW, Bruckner DA. DNA probe reactivity of Mycobacterium avium complex isolates from patients without AIDS. Diagnostic microbiology and infectious disease. 1988;11(3):125-8.

50. Falkinham 3rd J. Epidemiology of infection by nontuberculous mycobacteria. Clinical microbiology reviews. 1996;9(2):177.

51. Falkinham JO, Hilborn ED, Arduino MJ, Pruden A, Edwards MA. Epidemiology and ecology of opportunistic premise plumbing pathogens: Legionella pneumophila, Mycobacterium avium, and Pseudomonas aeruginosa. Environmental Health Perspectives. 2015;123(8):749-58.

52. Vaerewijck MJ, Huys G, Palomino JC, Swings J, Portaels F. Mycobacteria in drinking water distribution systems: ecology and significance for human health. FEMS Microbiology Reviews. 2005;29(5):911-34. 
53. Whiley H, Keegan A, Giglio S, Bentham R. Mycobacterium avium complex--the role of potable water in disease transmission. Journal Of Applied Microbiology. 2012;113(2):223-32.

54. Water Research Australia. Mycobacteria in drinking water. Adelaide South Australia; 2014.

55. Thomson RM. Characteristics of nontuberculous mycobacteria from a municipal water distribution system and their relevance to human infections. 2013.

56. Delafont V, Mougari F, Cambau E, Joyeux M, Bouchon D, Héchard Y, et al. First evidence of amoebae-mycobacteria association in drinking water network. Environmental Science and Technology. 2014;48(20):11872-82.

57. Beumer A, King D, Donohue M, Mistry J, Covert T, Pfaller S. Detection of mycobacterium avium subsp. paratuberculosis in drinking water and biofilms by quantitative PCR. Applied and Environmental Microbiology. 2010;76(21):7367-70.

58. Baird S, Taori S, Dave J, Willocks L, Roddie H, Hanson M. Cluster of non-tuberculous mycobacteraemia associated with water supply in a haemato-oncology unit. Journal of Hospital Infection. 2011;79(4):339-43.

59. Hussein Z, Landt O, Wirths B, Wellinghausen N. Detection of non-tuberculous mycobacteria in hospital water by culture and molecular methods. International Journal of Medical Microbiology. 2009;299(4):281-90.

60. Falkinham Iii JO, Iseman MD, de Haas P, van Soolingen D. Mycobacterium avium in a shower linked to pulmonary disease. Journal of Water and Health. 2008;6(2):209-13.

61. Wendt SL, George KL, Parker BC, Gruft H, Falkinham III JO. Epidemiology of infection by nontuberculous mycobacteria: III. Isolation of potentially pathogenic mycobacteria from aerosols. American Review of Respiratory Disease. 1980;122(2):259-63.

62. Parker BC, Ford MA, Gruft H, Falkinham III JO. Epidemiology of infection by nontuberculous mycobacteria: IV. Preferential aerosolization of Mycobacterium intracellulare from natural waters. American Review of Respiratory Disease. 1983;128(4):652-6.

63. Taylor RH, Falkinham JO, Norton CD, LeChevallier MW. Chlorine, chloramine, chlorine dioxide, and ozone susceptibility of Mycobacterium avium. Appl Environ Microbiol. 2000;66(4):1702-5.

64. Steed KA, Falkinham JO. Effect of growth in biofilms on chlorine susceptibility of Mycobacterium avium and Mycobacterium intracellulare. Appl Environ Microbiol. 2006;72(6):4007-11.

65. Pellett S, Bigley D, Grimes D. Distribution of Pseudomonas aeruginosa in a riverine ecosystem. Appl Environ Microbiol. 1983;45(1):328-32.

66. Ribas F, Perramon J, Terradillos A, Frias J, Lucena F. The Pseudomonas group as an indicator of potential regrowth in water distribution systems. Journal of Applied Microbiology. 2000;88(4):704-10.

67. Spencer R. Predominant pathogens found in the European prevalence of infection in intensive care study. European Journal of Clinical Microbiology and Infectious Diseases. 1996;15(4):281-5.

68. Anaissie EJ, Penzak SR, Dignani MC. The hospital water supply as a source of nosocomial infections: A plea for action. Archives of Internal Medicine. 2002;162(13):1483-92.

69. Tissot F, Blanc DS, Basset P, Zanetti G, Berger MM, Que YA, et al. New genotyping method discovers sustained nosocomial Pseudomonas aeruginosa outbreak in an intensive care burn unit. Journal of Hospital Infection. 2016;94(1):2-7.

70. Caskey S, Stirling J, Moore JE, Rendall JC. Occurrence of Pseudomonas aeruginosa in waters: Implications for patients with cystic fibrosis (CF). Letters in Applied Microbiology. 2018;66(6):537-41. 
71. Leoni E, Sanna T, Zanetti F, Dallolio L. Controlling Legionella and Pseudomonas aeruginosa re-growth in therapeutic spas: Implementation of physical disinfection treatments, including UV/ultrafiltration, in a respiratory hydrotherapy system. Journal of Water and Health. 2015;13(4):996-1005.

72. Grobe S, Wingender J, Flemming H-C. Capability of mucoid Pseudomonas aeruginosa to survive in chlorinated water. International journal of hygiene and environmental health. 2001;204(2-3):139-42.

73. Lee CS, Wetzel K, Buckley T, Wozniak D, Lee J. Rapid and sensitive detection of Pseudomonas aeruginosa in chlorinated water and aerosols targeting gyrB gene using real-time PCR. Journal of applied microbiology. 2011;111(4):893-903.

74. Michel R, Müller K-D, Amann R, Schmid E. Legionella-like slender rods multiplying within a strain of Acanthamoeba sp. isolated from drinking water. Parasitology research. 1997;84(1):84-8.

75. Hoffmann R, Michel R. Distribution of free-living amoebae (FLA) during preparation and supply of drinking water. International journal of hygiene and environmental health. 2001;203(3):215-9.

76. Marciano-Cabral F, Jamerson M, Kaneshiro ES. Free-living amoebae, Legionella and Mycobacterium in tap water supplied by a municipal drinking water utility in the USA. Journal of water and health. 2010;8(1):71-82.

77. Muchesa P, Barnard TG, Bartie C. The prevalence of free-living amoebae in a South African hospital water distribution system. South African Journal of Science. 2015;111(1-2):01-3.

78. Bagheri H, Shafiei R, Shafiei F, Sajjadi S. Isolation of acanthamoeba spp. From drinking waters in several hospitals of iran. Iranian journal of parasitology. 2010;5(2):19.

79. Chang CW, Wu YC, Ming KW. Evaluation of real-time PCR methods for quantification of Acanthamoeba in anthropogenic water and biofilms. Journal of Applied Microbiology. 2010;109(3):799-807.

80. Khan NA. Acanthamoeba: biology and increasing importance in human health. FEMS microbiology reviews. 2006;30(4):564-95.

81. King CH, Shotts EB, Wooley RE, Porter KG. Survival of coliforms and bacterial pathogens within protozoa during chlorination. Appl Environ Microbiol. 1988;54(12):3023-33.

82. Cirillo JD, Falkow S, Tompkins LS, Bermudez LE. Interaction of Mycobacterium avium with environmental amoebae enhances virulence. Infection and immunity. 1997;65(9):3759-67.

83. Thomas JM, Ashbolt NJ. Do free-living amoebae in treated drinking water systems present an emerging health risk? Environmental science \& technology. 2010;45(3):860-9.

84. Lin YE, Stout JE, Yu VL. Controlling Legionella in hospital drinking water: An evidence-based review of disinfection methods. Infection Control and Hospital Epidemiology. 2011;32(2):166-73.

85. Storey MV, Winiecka-Krusnell J, Ashbolt NJ, Stenström TA. The efficacy of heat and chlorine treatment against thermotolerant Acanthamoebae and Legionellae. Scandinavian Journal of Infectious Diseases. 2004;36(9):656-62.

86. Hochstrasser R, Hilbi H. Migration of Acanthamoeba castellanii Through Legionella Biofilms. Legionella: Springer; 2019. p. 79-89.

87. Wang H, Bedard E, Prevost M, Camper AK, Hill VR, Pruden A. Methodological approaches for monitoring opportunistic pathogens in premise plumbing: a review. Water research. 2017;117:68-86.

88. Marciano-Cabral F, MacLean R, Mensah A, LaPat-Polasko L. Identification of Naegleria fowleri in domestic water sources by nested PCR. Appl Environ Microbiol. 2003;69(10):5864-9.

89. Yoder JS, Straif-Bourgeois S, Roy SL, Moore TA, Visvesvara GS, Ratard RC, et al. Primary amebic meningoencephalitis deaths associated with sinus irrigation using contaminated tap water. Clinical Infectious Diseases. 2012;55(9):e79-e85. 
90. Cope JR, Ratard RC, Hill VR, Sokol T, Causey JJ, Yoder JS, et al. The first association of a primary amebic meningoencephalitis death with culturable Naegleria fowleri in tap water from a US treated public drinking water system. Clinical Infectious Diseases. 2015;60(8):e36-e42.

91. Anderson K, Jamieson A, Jadin J, Willaert E. Primary amoebic meningoencephalitis. Lancet. 1973.

92. Wellings F, Amuso P, Chang S, Lewis A. Isolation and identification of pathogenic Naegleria from Florida lakes. Appl Environ Microbiol. 1977;34(6):661-7.

93. Bartrand TA, Causey JJ, Clancy JL. Naegleria fowleri: An emerging drinking water pathogen. JournalAmerican Water Works Association. 2014;106(10):E418-E32.

94. Reyes-Batlle M, Rizo-Liendo A, Viera-Santana RA, Afonso-Morales S, López-Arencibia A, Sifaoui I, et al. Isolation and Molecular Identification of Naegleria australiensis in Irrigation Water of Fuerteventura Island, Spain. Acta parasitologica. 2019.

95. Waso M, Dobrowsky PH, Hamilton KA, Puzon G, Miller H, Khan W, et al. Abundance of Naegleria fowleri in roof-harvested rainwater tank samples from two continents. Environmental Science and Pollution Research. 2018;25(6):5700-10.

96. Sarkar P, Gerba CP. Inactivation of Naegleria Fowleri by chlorine and ultraviolet light. Journal - American Water Works Association. 2012;104(3):E173-E80.

97. Goudot S, Herbelin P, Mathieu L, Soreau S, Banas S, Jorand FPA. Biocidal efficacy of monochloramine against planktonic and biofilm-associated Naegleria fowleri cells. Journal of Applied Microbiology. 2014;116(4):1055-65.

98. Chang SL. Resistance of pathogenic Naegleria to some common physical and chemical agents. Applied and environmental microbiology. 1978;35(2):368-75.

99. Environmental Health Directorate. Amoeba Response Protocol. In: Department of Health WA, editor. Perth: Department of Health, Western Australia; 2014.

100. Ryota Sakamoto. Legionnaire's disease, weather and climate. World Health Organisation; 2015 January 23, 2015.

101. Beer KD, Gargano JW, Roberts VA, Hill VR, Garrison LE, Kutty PK, et al. Surveillance for Waterborne Disease Outbreaks Associated with Drinking Water - United States, 2011-2012. MMWR Morbidity and mortality weekly report. 2015;64(31):842.

102. Bartram J. Legionella and the prevention of legionellosis: World Health Organization; 2007.

103. Department of Health. National Notifiable Disease Surveillance System Canberra: Australia Government; 2019 [updated n.d.; cited 2019 June 23, 2019]. Available from: http://www9.health.gov.au/cda/source/rpt 3.cfm.

104. WA DoH. Legionellosis Notifications Perth, WA: Department of Health; 2009 [updated September 9, 2019; cited 2019 September 2019]. Available from: https://ww2.health.wa.gov.au/Articles/N R/Notifiable-infectious-disease-report?report=legionellosis.

105. Gompf SG, Garcia C. Lethal encounters: The evolving spectrum of amoebic meningoencephalitis. IDCases. 2019;15:e00524.

106. Yoder J, Eddy B, Visvesvara G, Capewell L, Beach M. The epidemiology of primary amoebic meningoencephalitis in the USA, 1962-2008. Epidemiology \& Infection. 2010;138(7):968-75.

107. NSW Health. Naegleria fowleri fact sheet New South Wales, Australia: NSW Government; 2017 [updated April 5, 2017; cited 2019 July 8, 2019]. Available from: https://www.health.nsw.gov.au/Infectious/factsheets/Pages/Naegleria-fowleri.aspx.

108. CDC. Parasites - Naegleria fowleri - Primary Amebic Meningoencephalitis (PAM) - Amebic Encephalitis: Centers for Disease Control and Prevention, National Center for Emerging and Zoonotic 
Infectious Diseases (NCEZID); 2019 [updated April 4, 2019; cited 2019 June 8, 2019]. Available from: https://www.cdc.gov/parasites/naegleria/illness.html.

109. Green M, Carnt N, Apel A, Stapleton F. Queensland Microbial Keratitis Database: 2005-2015. British Journal of Ophthalmology. 2019:bjophthalmol-2018-312881.

110. Thomson R, Donnan E, Konstantinos A. Notification of nontuberculous mycobacteria: an Australian perspective. Annals of the American Thoracic Society. 2017;14(3):318-23.

111. McLaughlin A, O'Gorman T. A local case of fulminant primary amoebic meningoencephalitis due to Naegleria fowleri. Rural \& Remote Health. 2019;19(2).

112. Henningson EW, Ahlberg MS. Evaluation of microbiological aerosol samplers: a review. Journal of Aerosol Science. 1994;25(8):1459-92.

113. Guyard C, Low DE. Legionella infections and travel associated legionellosis. Travel Medicine and Infectious Disease. 2011;9(4):176-86.

114. Nguyen TMN, Ilef D, Jarraud S, Rouil L, Campese C, Che D, et al. A community-wide outbreak of legionnaires disease linked to industrial cooling towers - How far can contaminated aerosols spread? Journal of Infectious Diseases. 2006;193(1):102-11.

115. White PS, Graham FF, Harte DJG, Baker MG, Ambrose CD, Humphrey ARG. Epidemiological investigation of a Legionnaires' disease outbreak in Christchurch, New Zealand: the value of spatial methods for practical public health. Epidemiology and infection. 2013;141(4):789.

116. Nygård K, Werner-Johansen Ø, Rønsen S, Caugant DA, Simonsen Ø, Kanestrøm A, et al. An outbreak of legionnaires disease caused by long-distance spread from an industrial air scrubber in Sarpsborg, Norway. Clinical Infectious Diseases. 2008;46(1):61-9.

117. Haupt TE, Heffernan RT, Kazmierczak JJ, Nehls-Lowe H, Rheineck B, Powell C, et al. An Outbreak of Legionnaires Disease Associated with a Decorative Water Wall Fountain in a Hospital. Infection Control and Hospital Epidemiology. 2012;33(2):185-91.

118. Glazer CS, Martyny JW, Lee B, Sanchez TL, Sells TM, Newman LS, et al. Nontuberculous mycobacteria in aerosol droplets and bulk water samples from therapy pools and hot tubs. Journal of Occupational \& Environmental Hygiene. 2007;4(11):831-40 10p.

119. Falkinham Iii JO. Nontuberculous mycobacteria from household plumbing of patients with nontuberculous mycobacteria disease. Emerging Infectious Diseases. 2011;17(3):419-24.

120. Bédard E, Laferrière C, Charron D, Lalancette C, Renaud C, Desmarais N, et al. Post-outbreak investigation of Pseudomonas aeruginosa faucet contamination by quantitative polymerase chain reaction and environmental factors affecting positivity. Infection Control and Hospital Epidemiology. 2015;36(11):1337-43.

121. Victor LY, Liu Z, Stout JE, Goetz A. Legionella disinfection of water distribution systems: principles, problems, and practice. Infection Control \& Hospital Epidemiology. 1993;14(10):567-70.

122. da Rocha-Azevedo B, Tanowitz HB, Marciano-Cabral F. Diagnosis of infections caused by pathogenic free-living amoebae. Interdisciplinary perspectives on infectious diseases. 2009;2009.

123. Ashbolt NJ. Environmental (Saprozoic) Pathogens of Engineered Water Systems: Understanding Their Ecology for Risk Assessment and Management. Pathogens (Basel, Switzerland). 2015;4(2):390-405.

124. Wingender J, Flemming H-C. Biofilms in drinking water and their role as reservoir for pathogens. International journal of hygiene and environmental health. 2011;214(6):417. 
125. Ledwoch K, Dancer SJ, Otter JA, Kerr K, Roposte D, Rushton L, et al. Beware biofilm! Dry biofilms containing bacterial pathogens on multiple healthcare surfaces; A multi-centre study. The Journal of hospital infection. 2018;100(3):e47-e56.

126. Bridier A, Sanchez-Vizuete P, Guilbaud M, Piard JC, Naïtali M, Briandet R. Biofilm-associated persistence of food-borne pathogens. Food Microbiology. 2015;45(Part B):167-78.

127. Pande VV, McWhorter AR, Chousalkar KK. Salmonella enterica isolates from layer farm environments are able to form biofilm on eggshell surfaces. Biofouling. 2016;32(7):699-710.

128. Soto-Giron MJ, Rodriguez-R LM, Luo C, Elk M, Ryu H, Hoelle J, et al. Biofilms on hospital shower hoses: Characterization and implications for nosocomial infections. Applied and Environmental Microbiology. 2016;82(9):2872-83.

129. Storey MV, Ashbolt NJ, Stenström TA. Biofilms, thermophilic amoebae and Legionella pneumophila - A quantitative risk assessment for distributed water. Water Science and Technology2004. p. 77-82.

130. Momba M, Kfir R, Venter SN, Cloete TE. Overview of biofilm formation in distribution systems and its impact on the deterioration of water quality. 2000.

131. Flemming H-C. Microbial biofouling: unsolved problems, insufficient approaches, and possible solutions. Biofilm highlights: Springer; 2011. p. 81-109.

132. O'Toole G, Kaplan HB, Kolter R. Biofilm formation as microbial development. Annual Reviews in Microbiology. 2000;54(1):49-79.

133. Ortolano GA, McAlister MB, Angelbeck JA, Schaffer J, Russell RL, Maynard E, et al. Hospital water point-of-use filtration: a complementary strategy to reduce the risk of nosocomial infection. American journal of infection control. 2005;33(5):S1-S19.

134. Flemming H-C, Percival S, Walker J. Contamination potential of biofilms in water distribution systems. Water science and technology: water supply. 2002;2(1):271-80.

135. Arnow PM, Weil D, Para MF. Prevalence and significance of Legionella pneumophila contamination of residential hot-tap water systems. Journal of Infectious Diseases. 1985;152(1):145-51.

136. Lin YsE, Vidic RD, Stout JE, Yu VL. Legionella in water distribution systems. Journal-American Water Works Association. 1998;90(9):112-22.

137. Bureau of Meteorology. Average annual and monthly maximum, minimum and mean temperatures Canberra: Australian Government; 2016 [updated November 2016; cited 2019 June 25, 2019]. Available from: http://www.bom.gov.au/jsp/ncc/climate averages/temperature/index.jsp.

138. Shire of East Pilbara Environmental Health Unit. Drinking Water Quality Results. [Water Monitoring Results]. In press 2019.

139. Wang H. Critical Factors Controlling Regrowth of Opportunistic Pathogens in Premise Plumbing: ProQuest Dissertations Publishing; 2013.

140. Lau HY, Ashbolt NJ. The role of biofilms and protozoa in Legionella pathogenesis: Implications for drinking water. Journal of Applied Microbiology. 2009;107(2):368-78.

141. Thomas V, McDonnell G, Denyer SP, Maillard J-Y. Free-living amoebae and their intracellular pathogenic microorganisms: risks for water quality. FEMS microbiology reviews. 2010;34(3):231-59.

142. Thomas V, Loret JF, Jousset M, Greub G. Biodiversity of amoebae and amoebae-resisting bacteria in a drinking water treatment plant. Environmental microbiology. 2008;10(10):2728-45.

143. Muchesa P, Barnard TG, Bartie C. The prevalence of free-living amoebae in a South African hospital water distribution system. SOUTH AFRICAN JOURNAL OF SCIENCE. 2015;111(1/2):80-1. 
144. Thomas V, McDonnell G. Relationship between mycobacteria and amoebae: ecological and epidemiological concerns. Letters in Applied Microbiology. 2007;45(4):349-57.

145. Matz C, Moreno AM, Alhede M, Manefield M, Hauser AR, Givskov M, et al. Pseudomonas aeruginosa uses type III secretion system to kill biofilm-associated amoebae. The ISME journal. 2008;2(8):843.

146. Shire of East Pilbara. Shire of East Pilbara Annual Report 2016 - 2017. Perth: Shire of East Pilbara; 2017.

147. Shire of East Pilbara. Shire of East Pilbara Annual Report 2017 - 2018. Perth; 2018.

148. Environmental Health Directorate. Chlorinated drinking water Perth: WA Department of Health; 2016 [June 20. 2019]. Available from: https://ww2.health.wa.gov.au/Articles/A E/Chlorinated-drinking-water.

149. Boorman GA. Drinking water disinfection byproducts: review and approach to toxicity evaluation. Environmental Health Perspectives. 1999;107(suppl 1):207-17.

150. NHMRC. Australian Drinking Water Guidelines Paper 6 National Water Quality Management Strategy, Canberra: National Resource Management Ministerial Council; 2011 [cited 2019 June 21, 2019]. Available from:

https://www.nhmrc.gov.au/about-us/publications/australian-drinking-water-guidelines\#block-views-bloc k-file-attachments-content-block-1.

151. Bowman G, Mealy R. The Fundamentals of Chlorine Chemistry and Disinfection. The Wisconsin State Lab of Hygiene and The Wisconsin Dept of Natural Resources: Madison, WI, USA. 2007.

152. Lloyd D, Turner N, Khunkitti W, Hann A, Furr J, Russell A. Encystation in Acanthamoeba castellanii: Development of Biocide Resistance 1. Journal of Eukaryotic Microbiology. 2001;48(1):11-6.

153. De Beer D, Stoodley P, Roe F, Lewandowski Z. Effects of biofilm structures on oxygen distribution and mass transport. Biotechnology and bioengineering. 1994;43(11):1131-8.

154. Rogers J, Dowsett A, Dennis P, Lee J, Keevil C. Influence of plumbing materials on biofilm formation and growth of Legionella pneumophila in potable water systems. Appl Environ Microbiol. 1994;60(6):1842-51.

155. Environmental Health Directorate.

Drinking water in Western Australia Perth: WA Department of Health; n.d. [cited 2019 June 21, 2019]. Available

from:

https://ww2.health.wa.gov.au/sitecore/content/Healthy-WA/Articles/A E/Drinking-water-in-Western-Au stralia.

156. Kalmbach S, Manz W, Szewzyk U. Dynamics of biofilm formation in drinking water: phylogenetic affiliation and metabolic potential of single cells assessed by formazan reduction and in situ hybridization. FEMS Microbiology Ecology. 1997;22(4):265-79.

157. Zhang Y, Edwards M. Accelerated chloramine decay and microbial growth by nitrification in premise plumbing. American Water Works Association Journal. 2009;101(11):51-62.

158. van der Kooij D, Veenendaal HR, Scheffer WJ. Biofilm formation and multiplication of Legionella in a model warm water system with pipes of copper, stainless steel and cross-linked polyethylene. Water research. 2005;39(13):2789-98.

159. Falkinham JO, Norton CD, LeChevallier MW. Factors influencing numbers of Mycobacterium avium, Mycobacterium intracellulare, and other mycobacteria in drinking water distribution systems. Appl Environ Microbiol. 2001;67(3):1225-31. 